\title{
The Analysis of Ecological Footprint at Farming Production Centre Cluster of MIFEE Program in Merauke Papua
}

\author{
Irba Djaja ${ }^{1,2 . *}, P$. Purwanto $^{1,3}$, H. R. Sunoko ${ }^{1,4}$, and Muslihudin Muslihudin ${ }^{5}$ \\ ${ }^{1}$ Agrotechnology Faculty University of Musamus Merauke Indonesia \\ ${ }^{2}$ Doctoral Program of Environmental Science, School of Postgraduate Studies, Diponegoro University, Semarang Indonesia \\ ${ }^{3}$ Department of Chemical Engineering, Faculty of Engineering, Diponegoro University, Semarang Indonesia \\ ${ }^{4}$ Department of pharmacy, Faculty of Medical, Diponegoro University, Semarang Indonesia \\ ${ }^{5}$ Sociology Department, Faculty of Social and Political Sciences, Jenderal Soedirman University, Purwokerto, Indonesia
}

\begin{abstract}
The heading Ecological footprint is one of the methods developed to respond sustainable development issue expected to measure the availability and usage of natural resources affecting the ecology of environment. The purpose of this study is to count the value of ecological footprint at Farming Production Centre Merauke through the supply and demand approach based on GFN (Global Footprint Network) and count the capacity of environment. The method used was Global Footprint Network, and counting capacity method. The results of ecological footprint counting was 29.9536 gha/inhabitant and the value of bio-capacity (supply) was gha/inhabitant, so the ecology (environmental support) value was 1,1936gha/inhabitant. The results show that the Farming Production Centre is categorized into ecological surplus and the capacity is 36,8964inhabitants/ ha. The value shows that the environment and ecosystem condition in the development area of Farming Production Centre in Merauke, Merauke Integrated Food and Energy Estate, is able to accommodate the needs and support the people living in the area (ecological debt).
\end{abstract}

Keywords: ecological footprint; bio-capacity; environment capacity.

\section{Introduction}

The 2011 Merauke Regency was designated as the National Food Barn and became a development platform for Agropolitan, Agro-tourism and Agro-industry in Eastern Indonesia (MP3EI 2011-2025 Coordinating Ministry for Economic Affairs, 2011). The alternative program developed was the Integrated and Integrated Employee Development Program at the Integrated Food and Energy Estate (MIFEE) with an area of 1.2 million hectares. The Concept of Development of the MIFEE Program which uses a very wide range of 1.2 million meters is not planned with either the environment does not take into account the capacity to supply and demand environmental impacts on the environment, disruption of the ecosystem, risk of water resources and loss of biodiversity. Therefore, to analyze the ability to support the impact of the development of the MIFEE Program, 1.2 Million $\mathrm{Ha}$ on the environment, an analytical assessment of the ecology to find out about the support of the environment in the KSPP development 1.2 million ha MIFEE program was carried out to build sustainable resources.

The calculation and analysis of the ecological footprint at the KSPP MIFEE Program area in Merauke use a method developed by Global Footprint Network (GFN-USA) in Working Guidebook to the National Footprint Account. In this method, demand is depicted as the final result from ecological footprint at an area while supply is the bio-capacity form. By using the principle of demand and supply, also the number of people and wide of the area to determine the area capacity based on bio-capacity at the KSPP MIFEE Program area. The condition expected is the lower value of demand/ ecological footprint than supply/ biocapacity value and the higher than 1 (one) value of area capacity to grant the resources usage continuity at KSPP MIFEE Program.

\section{Method}

The method used to analyze the ecological footprint in the KSPP development area 1, 2 million Ha program is a method developed by the Global Footprint Network (GFN-USA) in the Working Guidebook to the National Footprint Account and guidelines for determining the status of land carrying capacity and water carrying capacity Ministry of Environment in 2008 [1]. This method is based on calculating demand (Demand/Ecological Footprint (EF) and Biocapacity $(\mathrm{BK} / \mathrm{BC})$ for all land categories. The calculation results are used for Ecological Footprint Deficit (ED) Calculation and Calculation of capacity biocapacitybased region.

* Corresponding author: irba@unmus.ac.id 


\subsection{Demand/Ecological Calculation \\ Ecological footprint for all categories is counted using the equity:

$$
E F=\frac{P}{Y_{N}} Y F \cdot E Q F
$$ \\ Note: \\ $\mathrm{EF}=$ ecological footprint; \\ $\mathrm{P} \quad=$ the number of products harvested or emission produced; \\ $\mathrm{YN}=$ average national productivity for $\mathrm{P}$; \\ $\mathrm{YF}=$ yield factor; \\ $\mathrm{EQF}=$ equivalence factor.}

\subsection{Supply/Bio-capacity Calculation (BC)}

Bio-capacity for all categories is counted using the following equity [2]

$$
\begin{gathered}
\mathrm{BKi}=(0,88 \times \mathrm{LPLi} \times \mathrm{FP}) / \mathrm{JP} \\
B K i=\sum_{i=1}^{k} B K i
\end{gathered}
$$

Note:

$\mathrm{BK}, \quad=$ bio-capacity area usage (ha/inhabitant)

LPLi $=$ the wide of area usage (ha)

$0,88=$ Constanta $(12 \%$ of it is used to grant the bio diversity continuity (WWF, ZSL, dan GFN)

$\mathrm{FPi}=$ production factor $\mathrm{i}$ (Ferguson, 1998)

$\mathrm{JP} \quad=$ Number of people (inhabitant)

Table 1. Equivalent Factor of each Bio Productivity Area

\begin{tabular}{|l|l|c|}
\hline No & Bio- Productive Area & $\begin{array}{c}\text { Equivalent Factor } \\
\text { (Gha/Ha) }\end{array}$ \\
\hline 1 & Farming Area & 2.52 \\
\hline 2 & Shepherding Area & 0.43 \\
\hline 3 & Forest & 1.28 \\
\hline 4 & Waters & 0.35 \\
\hline 5 & Built-Up Area & 2.2 \\
\hline 6 & Inland Fishing Ground & 0.35 \\
\hline 7 & Fossilized Fuel (Forest) & 1.28 \\
\hline \multicolumn{2}{|c|}{ Source: $[2]$}
\end{tabular}

\subsection{Ecological Footprint Deficit (ED) Calculation}

Ecological deficit is counted using the equity:

$$
\mathbf{E D}=\mathbf{E F} \text { total }-\mathbf{B C}_{\text {total }}
$$

Note:

$\mathrm{ED}=$ ecological deficit;

$\mathrm{EF}_{\text {total }}=$ total ecological footprint;
$\mathrm{BC}_{\text {total }}=$ total bio-capacity

\subsection{Bio-capacity-based Calculation \\ Area \\ Capacity}

Determining the capacity area with bio-capacity-based at KSPP MIFEE can be done using the equity [3]:

$$
D T_{w}=\frac{L W}{\sum\left(J P . \propto_{1}+j P . \propto_{2}+j P . \propto_{N}\right)}
$$

Note:

DTw = area capacity based on bio-capacity

JP $=$ Number of people

$\alpha 1=$ area needed per capita for certain need (ha/ capita); it can use either Indonesia or world standard

$\mathrm{LW}=$ area width (ha)

The range of area capacity is:

1. If $\mathrm{DTw}>1$, it can be defined that the area is able to accommodate the needs of people and facilitate the people there and be developed.

2. If $\mathrm{DTw}<1$, it can be defined that the area is not able to accommodate the needs of people and the upcoming ones, so the area is beyond its capacity and needs to be protected (may not be developed).

\section{Results and Discussion}

\subsection{Calculation on Demand Global Footprint Network}

The calculation on ecological footprint at the KSPP MIFEE Program area is based on the people production at 6 districts (districts Ulilin, districts Elikobel, districts Muting, districts Semangga, districts Tanah Miring and districts Animha around the area. The production value has resulted form kinds of production, such as; farming, cattle breeding, fishery, and land. The productivity value used is based on the national productivity average. The calculation steps in this GFN method are; (1) identifying all production items of the population both goods and, (2) Calculating harvest factor value of each commodity especially on farming area, and (3) for carbon absorption area category, calculating the carbon absorption capacity of each land cover. The calculation on demand value based on GFN can be seen in Table 2. 
Table 2. Demand Calculation at KSPP MIFEE Program in Merauke

\begin{tabular}{|c|c|c|c|c|c|c|c|}
\hline \multirow[t]{2}{*}{ No } & \multirow[t]{2}{*}{ Area Usage } & Production & Productivity & $\begin{array}{c}\text { Similar } \\
\text { Factor }\end{array}$ & $\begin{array}{l}\text { Area } \\
\text { Used }\end{array}$ & $\begin{array}{c}\text { Number } \\
\text { of People }\end{array}$ & Demand \\
\hline & & ton/year & ton/ha/year & gha/ha & Gha & inhabitant & gha/inhabitant \\
\hline \multirow[t]{3}{*}{1} & Farming Area & & & & & & \\
\hline & \begin{tabular}{l|l|}
$\mathrm{a}$ & Food \\
\end{tabular} & $90,057.22$ & 4.88 & 2.51 & $46,375.82$ & 49,181 & 0.9426 \\
\hline & \begin{tabular}{l|l|}
$\mathrm{b}$ & Agriculture \\
\end{tabular} & $25,156.04$ & 1.56 & 2.51 & $20,274.39$ & 49,181 & 0.1743 \\
\hline \multirow[t]{2}{*}{2} & \multicolumn{7}{|c|}{ Cattle Breeding Area } \\
\hline & Cattle population & 7,593 & 0.11 & 0.46 & $32,063.72$ & 49.181 & 0.6520 \\
\hline \multirow[t]{2}{*}{3} & \multicolumn{7}{|l|}{ Fishery Area } \\
\hline & Inland Fishery & 99,636 & 15.82 & 1.26 & $7,933.72$ & 49,181 & 0.1613 \\
\hline \multirow[t]{2}{*}{4} & \multicolumn{7}{|l|}{ Forestry area } \\
\hline & Wood & $685,641.57$ & 1.64 & 0.37 & $154,611.29$ & 49,181 & 3,1437 \\
\hline \multirow[t]{2}{*}{5} & \multicolumn{7}{|l|}{ Built-Up Area } \\
\hline & Housing (ha) & $48,846.96$ & 1.13 & 2.51 & $108,445.68$ & 49,181 & 2,2052 \\
\hline \multirow[t]{2}{*}{6} & \multicolumn{7}{|c|}{ Carbon Absorption Area } \\
\hline & Forest & $140,571.04$ & 0.17 & 1,37 & $1,115,150.67$ & 49,181 & 22,6744 \\
\hline
\end{tabular}

Source: [4]

The results of demand calculation based on the Global Footprint Network (GFN) in Table 1 show the total resources demand on various usage of the area at KSPP MIFEE Program in Meraukeis 29,9936gha/inhabitant. The category of area usage on carbon absorption is the factor of the highest resource demand with 22,6744gha/inhabitant and other categories on area usage, fishery area, is the factor of the lowest resource demand with $0.1613 \mathrm{gha} /$ inhabitant.

\subsection{The calculation of supply based on Global Footprint Network}

The value of supply and bio-capacity is based on the amount of water and area in a productive area that is biologically provided inside the border of an area. Bio capacity is counted based on 5 kinds of area usage; farming area, cattle area, fishery area (sea waters and inland waters), forestry, and built-up land. Built-upland is counted because of the cover of buildings and infrastructures filling bio-capacity, the carbon absorption area is assumed as all carbon absorption as the demand of forestry bio-capacity (GFN).

Table 3. The calculation of Supply of Farming Production Centre at MIFEE Program area in Merauke

\begin{tabular}{|c|c|c|c|c|c|c|c|}
\hline \multirow[t]{2}{*}{ No } & \multirow[t]{2}{*}{ Area Usage } & Width & $\begin{array}{l}\text { Harvest } \\
\text { Factors }\end{array}$ & $\begin{array}{l}\text { Similar } \\
\text { Factor }\end{array}$ & $\begin{array}{c}\text { Land } \\
\text { Availability }\end{array}$ & $\begin{array}{l}\text { Number of } \\
\text { inhabitants }\end{array}$ & Supply \\
\hline & & $\mathrm{Ha}$ & & gha/ha & gha & inhabitant & gha/inhabitant \\
\hline \multirow[t]{3}{*}{1} & \multicolumn{7}{|l|}{ Farming Area } \\
\hline & \begin{tabular}{l|l}
$\mathrm{a}$ & Food \\
\end{tabular} & $18,469.25$ & 4.88 & 2.51 & $46,357.82$ & 49,181 & 0.9439 \\
\hline & Agriculture & 3,416 & 0.05 & $8,574.16$ & $49,112.00$ & 49,181 & 0.1746 \\
\hline \multirow[t]{2}{*}{2} & \multicolumn{7}{|c|}{ Cattle breeding area } \\
\hline & Population & $69,703.74$ & 1.81 & 0.46 & $17,714.76$ & 49,181 & 0.3602 \\
\hline \multirow[t]{2}{*}{3} & Fishery area & & & & & & \\
\hline & Inland fishery & $6,296.30$ & 3.36 & 1.26 & $2,361.11$ & 49,181 & 0.0480 \\
\hline \multirow[t]{2}{*}{4} & Forestry & & & & & & \\
\hline & \multirow{2}{*}{$\begin{array}{l}\text { Wood } \\
\text { Built- up area }\end{array}$} & $417,868.34$ & 0.82 & 0.37 & $188,550.35$ & 49,181 & 3,8338 \\
\hline \multirow[t]{2}{*}{5} & & & & & & & \\
\hline & Housing & $43,209.43$ & 0.98 & 2.51 & $110,669.06$ & 49,181 & 2,2502 \\
\hline \multirow[t]{2}{*}{6} & \multicolumn{7}{|c|}{ Carbon absorption area } \\
\hline & Forest & $813,978.59$ & 0.82 & 1.37 & $1,359,939.85$ & 49,181 & 27,6517 \\
\hline & & & & & & Total Supply & $\mathbf{3 5 , 8 1 2 0}$ \\
\hline
\end{tabular}

Sources: [4]

The results from supply calculation show the availability of the resources at the MIFEE program is 35.8120 gha/inhabitant. The highest resources supply is the category of carbon absorption with $27,6517 \mathrm{gha} /$ inhabitant and the lowest resources supply is fishery category with 0.0480 gha/inhabitant. The low land use category for land fisheries is caused by the low land use for inland aquaculture by the community and local government and other factors are the area in the KSPP development area. The results of supply value are presented in Table 3. 


\subsection{Ecological Calculation \\ Footprint Deficit}

The ecological deficit (ED) calculation is based on the calculation value of demand and supply using GFN and shown in Table 4.

Table 4. The calculation of ED at MIFEE Program area in Merauke

\begin{tabular}{|c|l|c|c|c|l|}
\hline No & \multicolumn{1}{|c|}{$\begin{array}{c}\text { Area } \\
\text { Usage }\end{array}$} & Demand & Supply & $\begin{array}{c}\text { Ecological } \\
\text { Footprint } \\
\text { Deficit } \\
\text { (ED) }\end{array}$ & $\begin{array}{l}\text { Ecological } \\
\text { Footprint }\end{array}$ \\
\hline 1 & $\begin{array}{l}\text { Farming } \\
\text { area }\end{array}$ & 1.1169 & 1.6681 & 0.5496 & Surplus \\
\hline 2 & $\begin{array}{l}\text { Cattle } \\
\text { breeding } \\
\text { area }\end{array}$ & 0.6520 & 0.3602 & -0.2927 & Deficit \\
\hline 3 & $\begin{array}{l}\text { Fishery } \\
\text { area }\end{array}$ & 0.1613 & 0.0480 & -0.1135 & Deficit \\
\hline 4 & $\begin{array}{l}\text { Forestry } \\
\text { area }\end{array}$ & 3.1437 & 3.8338 & 0.6857 & Surplus \\
\hline 5 & $\begin{array}{l}\text { Built-up } \\
\text { area }\end{array}$ & 2.2052 & 2.2502 & 0.0419 & Surplus \\
\hline 6 & $\begin{array}{l}\text { Carbon } \\
\text { absorption } \\
\text { area }\end{array}$ & 22.6744 & 27.6517 & 4.9454 & Surplus \\
\hline & \multicolumn{2}{|l|}{29.9936} & 35.8120 & 5.8585 & Surplus \\
\hline
\end{tabular}

Source: [4]

The results show the value of Ecological Deficit (ED) is $5,8585 \mathrm{gha} /$ inhabitant. This shows the whole area of MIFEE Program in Merauke is on land resources surplus. This condition is relatively safe, in spite of the high demand of carbon absorption and forestry area, to accommodate the demand on resources. The condition of cattle breeding and fishery are on deficit where the supply cannot fulfill the high demand.

The comparison of the ecological footprint (demand) and bio-capacity (supply) can determine the value of environmental support [2]. If ecological footprint (demand) is higher than bio-capacity (supply), there will be ecological deficit; meaning the overshoot on environmental support and vice versa; if ecological footprint (demand) is lower than bio-capacity (supply), there will be surplus (sustainable) meaning there is enough bio-capacity in nature to support life (ecological debt) [3].

The results show that ecological footprint (demand) calculation is $29,9536 \mathrm{gha} /$ inhabitant and bio-capacity value (supply) is $35.8120 \mathrm{gha} /$ inhabitant so the value of environmental support value (ecology) (DDE) is:

$$
\mathrm{DDE}=\frac{\text { bio }- \text { capacity }(\text { supply })}{\text { ecological footprint }(\text { demand })}
$$

\section{$\mathrm{DDE}=35.8120 \mathrm{gha} / \mathrm{inh} a b i \operatorname{tant} / 29,9935 \mathrm{gha} /$ inhabitant} $\mathrm{DDE}=1,1939$

The result of the calculation is $1,1939 \mathrm{gha} /$ inhabitant. This means the value of DDE $>1$ and it shows the area is still on surplus where the ecosystem can support the people living there (ecological debt).

According to the analysis and observation, the amount of demand for farming, cattle breeding, forestry, and built-up area is affected by: 1) the high demand on farming area, 2) the effect of forest conversion into agriculture area, 3) the high demand from society on meat and fish consumption as primary needs, 4) the high demand on wood for housing needs, 5) the growth of people leading to the needs of built-up area, 6) the change of land covering.

The development of the MIFEE Program area in Merauke needs 1.2 million hectares of land causing the high demands on land resources for farming both arable land and cultivated land. By considering the supply and demand, it shows the farming area still becomes the foundation of the production system to accommodate the resources consumption of people at the MIFEE program development area.

Cattle breeding and fishery area are on deficit where the demand for meat and fish is higher than the supply of cattle and fish. To overcome the problem, the government; through Food Security, Cattle Breeding, and Animal Health Office of Merauke; issues the special policy on cow breeding to prevent cows cut. This is expected to maintain the availability of cows and the area of shepherding.

The rise in people's growth at the MIFEE Program area causes a higher demand in the built-up area. The faster the economic growth in the area also causes higher needs from the people on land. The rise in people's growth also causes land conversion implying on the decrease in land production ability. The factors causing land conversion implying on the decrease of production ability are the rise in housing areas caused by people's growth, the rise in the non-farming area for industry, service, and infrastructures [5].

The high demand for forest products for various needs of people and the conversion of forest area into agriculture influences the ecological footprint value though the analysis results show a surplus, but it tends to decrease. The tree cutting at forest area and other conservation area done by people for both illegal logging and opening new agriculture area have become a serious threat for flora and fauna in the area.

Another problem may occur is the at forest conversion may disturb the endemic fauna of Papua such as Cendrawasih, Mambruk birds, deers, and arwana fish also other endemic and protected fauna. Besides, the catch, hunt, and commercialization of endemic fauna are getting higher. If this condition is not getting any attention, it will be considered as creating ecosystem imbalance and natural disasters in a few upcoming years [6].

Although thoroughly the ecology footprint condition at the MIFEE Program area is still surplus, the resources demand on development activities of 1.2 million hectares can become the most dominant factor of ecology deficit in the area. It can be seen from the high comparison of supply and demand on the carbon absorption area. The high value of carbon absorption area is caused by the investment done for wide 
agriculture area by changing forest into monoculture agriculture and causing exploitation on forest resources at MIFEE program area so the forest area is decreasing leading to damage on the natural ecosystem, biodiversity, decrease of water debt even loss of water spring.

It goes along with research done by [7] where a gradual ecological surplus can change into the ecological deficit with population rising and farming area decrease. The irrational and inefficient use of sources can worsen the ecological deficit. The decrease in water debit is caused by less water absorption related to illegal logging and land conversion into the monoculture area causing a decrease in the quality of water absorption area. The high demand for wood from the forest will affect the higher demand for the carbon absorption area. High usage of fuel with excessive gas emission (pollution) or others, like; forest logging, industrial process [8] will affect the wide forest and carbon absorption area.

\subsection{Environment Capacity}

The analysis of environment capacity was counted using comparative principles between demand and supply of area with the standard value of area needed per inhabitant and calculated with the number of people and width of area. The calculation of environment capacity is presented in Table 5 .

Table 5. The Calculation of Environment Capacity at Farming Production Centre of MIFEE Program in Merauke

\begin{tabular}{|l|l|r|r|r|r|}
\hline No & \multicolumn{1}{|c|}{ Area Usage } & Width (Ha) & Number of People (JP) & $\begin{array}{c}\text { Area Chriteria } \\
\text { (KL) }\end{array}$ & $\begin{array}{c}\text { JP xKL } \\
\text { (inhabitants/ha) }\end{array}$ \\
\hline 1 & Farming area & $25,156.04$ & 49,112 & 0.013 & 638,4560 \\
\hline 2 & Cattle area & $69,703.74$ & 49,112 & 0.072 & $3,536.0640$ \\
\hline 3 & Forestry area & $417,868.34$ & 49,112 & 0.210 & $10,313.5200$ \\
\hline 4 & Built-up area & $43,209.43$ & 49,112 & 0.260 & $12,769.1200$ \\
\hline 5 & $\begin{array}{l}\text { Carbon absorption } \\
\text { area }\end{array}$ & $813,978.59$ & 49,112 & 0.201 & $9,871.5120$ \\
\hline & Total & $1,369,916.15$ & & & $36,424.84$ \\
\hline
\end{tabular}

Source: [4]

$$
\begin{aligned}
D T_{w} & =\frac{1,369,916.15 h a}{36,424.84 \text { inhabitants } / h a} \\
\mathrm{DT}_{\mathrm{w}} & =37,6094 \text { inhabitants/ha }
\end{aligned}
$$

The environment capacity at Farming Production Centre is 37.6094 inhabitants/ha. This value is bigger than 1 meaning that the area of MIFEE program is still able to accommodate the needs and the number of people and can be developed.

\section{Conclusion}

The analysis of ecological footprint at Farming Production Centre of MIFEE Program in Merauke is in resources surplus where the ecosystem in this area is able to support the people living in the area (ecological debt) with the value of EF resources demand is 29,9536 gha/inhabitant and the value of ecological deficit is 1.1956 gha/inhabitant.

\section{Gratitude}

1. Technical Institution of Merauke (Bappeda, Dinas Tanaman Pangan, Dinas PU Tata Ruang, Dinas Ketahanan Pangan Peternakan, dan Kesehatan
Hewan, Kabupaten Merauke) for giving the information and being informants in this study.

2. Field assistant team for assisting to gather data from field.

\section{References}

1. M.o. Environment, Working Guidebook to the National Footprint Account and guidelines for determining the status of land carrying capacity and water carrying capacity, Ministry of Environment (2008)

2. WWF, Living Planet Report Global Footprint (2006)

3. L. Mutaali, The Environmental Supporting Capacity for Regional Development Planning, Badan Penerbit Fakultas Geografi UGM (2012)

4. BPS, Merauke Regency in Figures, BPS Merauke Regency (2017)

5. Widiatmaka, W. Ambarwulan, A. Sutandi, K. Murtilaksono, K. Munibah, U. Daras, Suitable and Available Land For Cashew (anacardiumoc cidentale L.) in The Island of Lombok, Indonesia, Journal of Applied Horticulture 17(2), 129-139 (2015)

6. A. Saufi, F. Teguh, H. Ristanto, P. Basuki, O. Oehms, D. Vitriani, L. Creutz, H. Nuzullay, 
Lombok Island Sustainable Tourism Master Plan 2015-2019, West Nusa Tenggara Province Planning and Development Agency (2015)

7. M.C. Lin, S.L. Yan, Y. Li, The Studies of Ecological Environmental Quality Assessment in Anhui, Ecological Indicators 60, 879-883 (2016)

8. S. Rusli, W. Septri, I. Hana, Population Pressure, Java Island Ecological Overshoot, and Recovery Period. Jurnal Transdisiplin Sosiologi, Komunikasi,dan Ekologi Manusia 3(1) (2009) 